Uluslararası Mühendislik

\title{
Derin Maden Sondajlarında Ön İnceleme Așaması Mühendislik Yaklaşımları ve Fizibilite Etütlerinin Gerçekleştirilmesi
}

\section{Preliminary Stage Engineering Approaches in Deep Mining Drilling and Performing the Feasibility Investigations}

\author{
Mustafa Can Canoglu 1 \\ ${ }^{1}$ Sinop Üniversitesi, Mühendislik ve Mimarlık Fakültesi, 57000 Sinop, TÜRKİYE
}

Başvuru/Received: $26 / 02 / 2019$

Kabul/Accepted: 30/05/2019

Son Versiyon/Final Version: 30/06/2019

\begin{abstract}
Öz
Sondaj, sanayi devrimi sonrasında artan hammadde ihtiyacıyla beraber sıkça kullanılan bir yöntem haline gelmiştir. Özellikle 19. yüzyılın ikinci yarısından itibaren, başta madencilik sektörü olmak üzere, petrol, yeraltı suyu ve jeoteknik araştırmalarda derin ve sı̆̆ sondajlar gerçekleştirilmektedir. Bu çalışmada, yerbilimleri ve maden mühendisliğinin sektörel bazda en önemli iş dalı olan sondaj sektöründeki fizibilite aşaması arazi incelemeleri detaylandırılmıştır. Bu bağlamda, özellikle derin maden sondajları için gerçekleştirilen ön inceleme aşaması arazi incelemeleri ve fizibilite etütleri höristik mühendislik yaklaşımlarıyla gerçekleştirilmiştir. Bu mühendislik yaklaşımları, proje alanının lojistik durumu, makine personel ve ekipmanın proje alanına ulaşım olanakları, proje alanının işçi sağlığı ve güvenliği açısından değerlendirilmesi, klimatolojik koşulları, sondajın gerçekleştirileceği jeolojik formasyonun gözlemsel olarak sondaj performansına muhtemel etkileri gibi konuların yerinde değerlendirilmesiyle gerçekleştirilmiştir. Sondaj performansını arttırmaya yönelik kullanılacak sondaj katkıları, taşıyıcı ve soğutucu ajan olarak kullanılacak suyun temini ve zemin türüne uygun sondaj tekniğinin seçimi de bu çalışma kapsamında değerlendirilmiştir. Fizibilite aşamasındaki bir araştırma sondajına başlanmadan önce gerekli saha çalışmaları kapsamında gerçekleştirilecek incelemeler ve dikkat edilmesi gereken hususlar detaylandırılmıştır.
\end{abstract}

\section{Anahtar Kelimeler \\ "Sondaj, Maden araştırma sondajı, Derin sondaj, Sondaj fizibilite etütleri"}

\begin{abstract}
Drilling becomes a technique that is utilized frequently with the increase of raw material need after the industrial revolution. Deep and shallow drilling are implemented in petroleum, groundwater exploitation, geotechnical investigations and especially in mining industry since second part of the 19. century. In this study, feasibility stage field investigations of the drilling sector as the most important business segment of the engineering and mining geoscience is elaborated. In this context, preliminary stage of field examinations and feasibility investigations were fulfilled with heuristic engineering approaches. These engineering approaches consider the logistic situation of the project area, the transport possibilities of drill rig, drilling equipment and field staff, evaluation of the project area in terms of health and safety, climatological conditions and the possible effects of the geological conditions on the drilling performance. The utilization of drilling additives to increase the drilling performance, the water supply as the transporting and cooling agent and selection of appropriate drilling technique considering the ground conditions were assessed within this study. Before starting to an exploration drilling required feasibility stage examinations and points to consider were detailed.
\end{abstract}

Key Words

"Drilling, Mining exploration drilling, Deep drilling, Drilling feasibility investigations" 


\section{Giriş}

Türkiye'de jeoloji mühendisliği, hidrojeoloji mühendisliği, maden mühendisliği, jeofizik mühendisliği gibi yer bilimleri temelli mühendislik dallarının özel sektördeki iş imkânları içerisinde sondaj sektörü en çok mühendisi istihdam etmektedir. Özellikle, maden, petrol ve inşaat sektörlerinde kullanılan farklı sondaj teknikleri özel makine ve teçhizat ve tecrübeli teknik personel gerektirmektedir. Sondajlar mevcut hammadde olanaklarının niteliksel ve niceliksel olarak araştırılmasının yansıra, petrol ve yeraltı suyunun işletilmesi amaçlı olarak da açılmaktadır. Ayrıca, artan küresel ısınma tehdidine karşı yenilenebilir enerji kaynağı olan jeotermal kaynakların işletilmesinde de sondaj teknikleri çok önemli rol oynamaktadır. Sondajların inşaat sektöründe kullanımı ise jeoteknik amaçlı yerinde deney yapma ve numune almaya yönelik olabileceği gibi enjeksiyon gibi zemin iyileştirme yöntemlerinde de sondaj teknikleri kullanılmaktadır. Sondajlar, bilimsel araştırmalarda farklı amaçlar için birçok araştırmacı tarafından kullanılmıştır (Navarro vd. 2019; Sneddon vd. 2013; Kurtuluş \& Bozkurt, 2010; Özbayoğlu, 1979; Canoglu \& Kurtulus 2017(a); Canoglu \& Kurtulus 2017(b); Canoglu \& Gökkurt Baki, 2018; Canoglu, 2018, Cao vd. 2018).

Maden araştırma sondajlarının en büyük avantajı jeofizik yöntemlerle tam olarak belirlenemeyecek cevherleşme özelliklerinin net bir şekilde niteliksel ve niceliksel olarak boyutlandırılabilmesidir. Bir maden sahasında, sondajın işletmeye açılmadan önce gerçekleşmesi durumunda öngörülemeyen birçok mühendislik problemi sondajlarla belirlenebildiğinden işletme aşamasında öngörülen sorunlara önlem almak işletme maliyetlerini çok büyük oranda azaltmaktadır. Sondajların dezavantajı ise jeofizik yöntemlere göre daha pahalı olması, özel makine ve ekipman ve de tecrübeli personel gerektirmesidir. Sondajların bir diğer dezavantajı da operasyonlar sırasında kullanılan sondaj ekipmanlarının işçi sağlığı ve güvenliği açısından en riskli sınıfta olmasıdır. Her yıl sondajlarda birçok yaralanmalı, ağır yaralanmalı ve ölümlü kazalar gerçekleşmektedir. Bu durum uygun kişisel koruyucu ekipmanların kullanımı ve periyodik bakım gibi önlemlerle azaltılmaya çalışılsa da sondajlarda önemli bir dezavantaj olarak kabul edilmektedir.

Türkiye'de sondaj sektörü üç farklı alana hizmet etmektedir. Bu alanlardan en çok ekonomik getiriye sahip olan alan petrol endüstrisidir. Petrol sondajı diğer sektörler için gerçekleştirilen sondaj yöntemleri arasında en derin ve en karmaşık olanıdır. Sondaja ihtiyaç duyan diğer bir sektör ise jeotermal sektörüdür. Jeotemral enerji amaçlı açılan sondajlar da son derece pahalı, derin ve karmaşıktır. Sondaj sektöründe en uygun fiyatlı ve en basit sayılabilecek alan jeoteknik sondajlardır. Bu sondajlar genellikle jeoteknik veri elde etme amaçlı açılır ve fiyat olarak diğer sondaj türlerine göre daha uygundur. Bu çalışmanın da kapsamı içerisinde olan maden sondajları özellikle Türkiye'de son 20 yıldır çok gelişme kat etmiş ve Türkiye'yi sondaj makinesi ve ekipmanları üreten ve ihraç eden bir konuma getirmiştir. Bu nedenle, özellikle maden sondajları alanında gerçekleştirilen bilimsel ve uygulamaya yönelik çalışmaların ülke ekonomisine katı anlamında önemi büyüktür.

Gerçekleştirilen sondaj çalışmalarının performansını birbirinden bağımsız birçok parametre kontrol etmektedir. Bu parametreler içerisinde, sondörün tecrübesi, sondaj makinesinin teknik özellikleri ve dayanıklılı̆̆ı, sondajda kullanılan sondaj ekipmanının kalitesi ve zemin koşullarına uygunluğu, kullanılan sondaj katkı malzemelerinin doğru karışımlarla kullanılması gibi faktörler en önde gelenlerdir. Bunlarla beraber, sondaj platformunun geometrisi, soğutucu ve taşıyıcı ajan olarak kullanılacak sondaj suyu temini, sondaj yapılacak jeolojik formasyonun litolojik koşulları (sertlik, dağılma, dayanım, şişme, kohezyon vb.) da sondajın performansını ve projenin ekonomisini doğrudan etkileyebilmektedir. Bu nedenle, sondaja (özellikle derin maden sondajına) başlanmadan önce fizibilite aşamasında saha ön inceleme etütlerinin gerçekleştirilmesi proje ekonomisi ve sondaj performansının arttırılması açısından çok önemlidir. Ayrıca iyi etüt edilmeden başlanan sondajlarda çok fazla yakıt ve sondaj ekipmanı sarfiyatı olacak ve ilerleme çok yavaş gerçekleşecektir. Örneğin, zor zemin koşullarında ve kuyunun yıkılma riskinin olduğu bölgelerde gerçekleştirilen sondajları tecrübesi nispeten daha az sondörlerle gerçekleştirmek kuyu ve ekipman kaybı gibi büyük riskler taşır. Ayrıca, kullanılacak sondaj katkısının doğru zeminde doğru oranlarda kullanılmaması kuyuda yıkılmalara ve sondaj ekipmanının kuyu içerisinde sıkışmasına neden olur. Sondaj performansının ön inceleme aşamasında değerlendirildiği bu çalışma mühendislik yaklaşımları ve sondaj işleminin rantabilitesinin belirlenmesi açısından büyük önem taşımaktadır.

Bu çalışma kapsamında, gerçekleştirilecek sondaj operasyonlarının performansını arttırmak, projeyi daha ekonomik hale getirmek ve sondajda kullanılacak makine ve ekipmana karar verebilmek adına Arnavutluk'ta gerçekleştirilecek olan derin maden sondajları için fizibilite aşaması saha ön inceleme etütleri gerçekleştirilmiştir. Bu bağlamda, sondaj projesi, proje bölgesine makine ve personel ulaşımı, sondaj platformlarının geometrisi ve yerinde incelenmesi, sondaj sahasına proje içi ulaşım koşulları, bölgenin iklimi ve çalışmaya elverişliliği, sondaj yapılacak zeminin litolojik özellikleri ve sondaj suyu temini açısından değerlendirilmiştir.

\section{Materyal ve yöntem}

Sondaj projesine başlanmadan önce fizibilite aşaması saha incelemelerinin detaylı bir şekilde gerçekleştirilmesi ve raporlanması projenin rantabilitesi açısından büyük önem arz etmektedir. Saha incelemesine gerçekleştirilmeden önce, proje lokasyonu hakkında elde edilebilecek tüm bilgiler toplanmış proje sahası hava fotoğrafları ve uydu görüntülerinden incelenmiştir. Ayrıca, proje hakkındaki raporlar, fotoğraflar ve bilgiler toplanmıştır. Bununla beraber, saha yurtdışında olduğu için gidilecek ülkenin nüfusu, 
ekonomisi, sanayileşme durumu, mazot fiyatları, vergilendirme, sosyal güvenlik sistemi, sigorta gibi konular detaylıca araştırılmıştır.

\subsection{Proje bölgesine ulaşımın değerlendirilmesi}

Proje bölgesine ulaşım, ekip ulaşımı ve makine ulaşımı şeklinde iki şekilde incelenmiştir.

\subsubsection{Personel ulaşımı}

Sondaj sahasına ekip ulaşımı eğer çalışma sahası yurtdışında ise bazı komplikasyonları beraberinde getirebileceği göz önüne alınmıştır. Örneğin; gidilecek ülkenin Türkiye'den vize istemesi işleri bir miktar zorlaştırabilir. Ayrıca, ülkedeki çalışma ve oturma izinleri de sondaj personeli hareketliliği açısından önemlidir.

Ayrıca, sahaya ulaşımın ne kadar zaman aldığı, kaç km olduğu, ne kadar karayolu ne kadar havayoluyla gitmek gerektiği iyice etüt edilmiş ona göre bir çalışma planı ortaya koyulmuştur. Bununla beraber, her bir kuyu lokasyonu için personelin sahaya minimum sürede ulaşımının sağlanabileceği konaklama noktalarının seçimi de ayrıca önemlidir.

\subsubsection{Makine ve ekipman ulaşımı}

Ulaşımla ilgili önemli konulardan biri de makinenin proje bölgesine mobilizasyonudur. Sahaya ulaştırılacak sondaj makinesi ve ekipman miktarı göz önüne alınarak lojsitik bir plan yapılmış, söz konusu şantiye yurtdışında olduğu için, makine ve ekipmanın gümrükte kaç gün bekleyeceği öngörülmüş, gümrükte çıkabilecek sorunlar araştırılmıştır.

\subsubsection{Sondaj sahasına proje içi ulașım koșulları}

Sondaj sahasına proje için ulaşım yolları makine ve ekipman mobilizasyonu için önem taşımaktadır. Yolun eğimi, yolun yağmura karşı davranışı (kil içeriğine bağlı kayganlık), yolun genişliği vs. etüt sırasında göz önüne alınmıştır. Yolların durumu göz önüne alınırken, makinenin paletli olmasına rağmen bölgeye sağlanacak gerekli malzeme transferi de lojistik açıdan değerlendirilmiştir. Yani yolun eğimi 4x4 bir pick-up'ın rahatça tırmanabileceği durumda olup olmadığı incelenmiştir. Ayrıca bir ters dolaşımlı (RC) makinenin günde 600 litre mazot harcadığı göz önünde bulundurulursa, sondaj sahasına mazot taşınması konusu önem kazanacaktır. Eğer ortam çok eğimliyse ve variller pick-up üstünde gidemeyecek durumdaysa bu duruma bir çözüm getirmek gerekebilir (tanker ya da traktör kiralamak vs).

Bunlara ek olarak, makine çalışma sahasına en yakın nerede ve nasıl indirilebileceği de değerlendirilmiştir. Kullanılacak sondaj makinesinin ağırlığı ve işçi sağlığı güvenliği mevzuatı göz önüne alınarak en az 15 ton kapasiteli vinç ile sondaj makinesinin yüklenmesi ve indirilmesi planlanmıştır. Şantiye alanı ve yakın çevresinin vinç ile yükleme ve indirme için uygun olmadığı yerler için makinenin treylerden inebileceği topraktan bir rampa inşa edilmiş ve güvenli operasyon için rampanın kompaksiyonu planlanmıştır.

\subsection{Proje alanının genel koşulları ve sondaja elverişliliğinin değerlendirilmesi}

Proje alanı ve yakın çevresinin iklim koşulları sondaj operasyonlarının verimini ve işçi sağlığı güvenliğini doğrudan etkileyen bir durumdur. Sondaj projesinin fizibilite aşamasında klimatolojik koşullar açısından değerlendirilebilmesi için yıllık ortalama yağış, aylık ortalama yağış, aylık ortalama sıcaklıklar, aylık en yüksek ve en düşük sıcaklık değerleri gibi bilgilerin Türkiye'de Meteoroloji İşleri Genel Müdürlüğü, yurt dışında ise ilgili ülkenin meteoroloji birimleri tarafından elde edilmesi gerekir. Ayrıca, yağış miktarını tahmin etmek adına yeşil alan miktarı ve bitki örtüsünün de fikir verebileceği göz öngüne alınmalıdır.

Sondaj sahasının operasyonlara elverişli olabilmesini etkileyen bir diğer faktör de sondaj platformunun geometrisidir. Genel olarak bir sondaj makinesinin ebatları kaba olarak 3m x 5m dir. Güvenlik ekipmanları, araç giriş çıkışı, mazot varili, tij sehpası ve sondajın eğimli olarak yapılacağı da göz önüne alınırsa, minimum 10mx15m’lik bir sondaj platformu işlerin güvenli bir şekilde gerçekleştirilebilmesi için gereklidir. İşçi sağlığı ve güvenliği açısından çalışma sahası ne kadar büyük olursa o kadar iyi koşullarda ve güvenli iş yapılacağı ve sondaj operasyonlarının verimli olacağı göz önüne alınmıştır. Bununla beraber herhangi bir galeri ya da yeraltı açıklığında gerçekleştirilecek sondajlar için ise üst taraftan bir sınırlama olmasından dolayı sondaj kulesinin boyuna göre yeraltı açıklığının projelendirileceği değerlendirilmiştir. Ayrıca, maden sondajı için günümüzde kullanılan paletli sondaj makineleri \%20 eğimde operasyonları yürütebilecek kapasitedelerdir ancak eğimli alanlarda gerçekleştirilen sondaj operasyonlarında iş kazalarının daha sık görülmektedir.

Sondaj operasyonları için fizibilite aşamasında gözlenmesi gereken bir konu da sondaj yapılacak formasyonun fiziksel karakteristikleridir. Bu konuyla ilgili bilgi edinebilmek için proje alanı ile ilgili bilimsel literatür taranmış bölgenin jeoplojik haritası ve kolon kesiti elde edilmiştir. Böylece sondajı negatif yönde etkileyecek fay zonları, kırık çatlaklar, kohezyonsuz birimler, intrüzyon kontak zonları ve altere zonlar tespit edilmiştir. Sondaj operasyonları sırasında killi altere olmuş zonlar, ve intrüzyon kontak zonları ince taneli yapıya sahip olduklarından ekipmanın su girişini tıkayarak takım sıkışmasına neden olur. Ayrıca intrüzyon kontak zonları ve altere olmuş zonlar, dayanımsız olduğundan kuyu çökmesine neden olurlar. Bu tip durumlar çok 
öngörülebilir olmasa da fizibilite aşamasında gerçekleştirilen araştırmalar, sondaj ve ekipman planlaması için gerekli önlemlerin alınabilmesini sağlamaktadır. Bu önlemler, kullanılan polimerdeki kimyasal katkı maddelerinin oranının değiştirilmesiyle gerçekleşir bu da maliyeti arttırabilen bir faktördür. Kırık çatlaklı zonlarda ise karot verimi düşecektir ve manevra boyu azalacaktır, bu da göz önüne alınması gereken önemli bir durumdur. Kumlu zonlar ise kohezyonsuz olduğundan karot alınamaz, bunun için özel ekipman gerekir bu durumu da dikkate alınması gereken önemli konulardan biridir.

Tüm bu fiziksel özellikleri belirlenirken sahada varolan yarma ve/veya araştırma çukurları vs. incelenmiş kil oranı gözlemsel olarak belirlenmiş, plastisite indisi göz kararı dokunarak tahmin edilmiştir. Ayrıca eğer bölgede yapılan başka sondajlara ait bilgiler toplanmış ve karot örnekleri ve sondaj logları incelenmiştir. Bunların dışında, mineralize olmuş zonun tahmin edilen derinlik ve kalınlığı, RC ve karotlu kuyuların ortalama derinlikleri ve açıları ve de kuyular arası ortalama uzaklıklar da sondaj operasyonlarının ekonomik koşullarını ve rantabilitesini doğrudan etkilemektedir.

\subsubsection{Sondaj Suyu Temini}

Karotlu derin maden sondajlarında taşıyıcı ve soğutucu ajan olarak su kullanılmaktadır. Fizibilite aşamasındaki bir saha incelemesinde karotlu sondaj için delgi suyu temini adına en yakın yüzey suyunun yeri ve bulunduğu kot tespit edilmeli ve suyun basılacağı kota göre su pompası ve hortum proje için temin edilmelidir. Eğer su pompalamak akılcı değilse, tanker ya da diğer araçlarla suyun sondaj sahasına ulaşması konusu düşünülmelidir. Su kuyusu açmak mantıklıysa, bu konu da değerlendirmeye alınabilir. Söz konusu projede de su temini ile ilgili tüm bu konular dikkate alınmış ve en ekonomik seçenek göz önüne alınarak planlama yapılmıştır.

\subsubsection{RC ve Karotlu Sondaj Koşullart}

RC tip sondajın karotlu sondaja göre avantajları ve dezavantajları vardır. RC sondaj karotlu sondaja göre çok daha hızlı ilerleme imkanına sahiptir. Ancak, alınan numunede kaya ortamının kırık çatlak veya faylanma gibi yapısal özelliklerini yansıtmamaktadır. Ayrıca derinlik olarak RC sondaj karotlu sondaja göre çok saha sığdır ve RC sondajda uzmanlaşmış sondör ve işçi çalıştırmak gereklidir. Bunun dışında RC ekipmanları karotlu sondaj ekipmanlarına göre çok daha ağırdır ve iş kazaları açısından daha büyük risk taşımaktadır. Ayrıca, RC sondaj ekipmanı yapısı gereği yeraltısuyunun altındaki kotlarda verimsiz çalışmakta hatta çalışamamaktadır. Be nedenle, bölgede RC sondaj alternatifi için yeraltı suyu seviyesi ve artezyen durumu göz önünde bulundurulmuştur. Yeraltısuyu koşullarına dair sahada herhangi bir veri olmaması durumunda çalışma alanının topoğrafyası ve yüzey suyu koşullarından yeraltısuyu derinliği ile ilgili tahmin yürütülmüştür. Tüm bunlarla beraber, mineralize olmuş zonun tahmini derinliği ile RC ve karotlu sondaj makinalarının derinlik kapasiteleri karşılaştırılmış uygun makine tipi üzerinden planlama yapılmıştır.

\subsection{Personel konaklaması ve diğer konular}

Fizibilite aşamasındaki bir sondaj sahasının incelemesinde araştırılması gereken önemli konulardan bir diğeri de sondör ve işçi personel ile şantiye şefinin konaklaması ve proje içi sahaya ulaşımıdır. Bu konudaki önemli nokta, kalınacak yerin saha olan uzaklığıdır. Kalınacak yer sondaj sahasına mümkün olduğunca yakın rahat ve güvenli olmalıdır.

Saha incelemesinde, dikkat edilmesi ve araştırılması gereken diğer bir konu da çalışma alanının yakınlarında bir sanayi bölgesinin olup olmadığıdır. Bu nedenle, ihtiyaç duyulması halinde sondaj sahasının hemen yakınında tornacı, kaynakçı vs. bulunan bir sanayi bölgesinin olup olmadığı araştırılmış eğer yakınlarda yoksa bu tip temel sanayi işlevlerini görebilecek en yakın sanayi yerleşkesi tespit edilmiştir. Ayrıca, çalışılan bölgeye para transferi konusu da önem taşımaktadır. Söz konusu şantiye bir yurtdışı şantiyesi olduğundan çalışılacak bölgeye para transferi yapmanın en ucuz, en kolay ve en güvenli yolu araştırılmıştır. Bununla beraber, lokal işçi temini ile ilgili detaylar mevcut personelin izinli olduğu durumlar için araştırılmıştır. Son olarak da hem işçi sağlığı ve güvenliği açısından hem de projenin hızlı yürütülebilmesi açısından büyük önem taşıyan konulardan biri olan haberleşme konusu araştırılmıştır. Bölgede ve özellikle sondaj sahasında cep telefonunun çalışıp çalışmadığı, en ucuz ve en verimli GSM operatörü araştırılmıştır.

\section{Etüt edilen sondaj sahaları}

Çalışmaya konu olan Arnavutluk Ülkesinde 5 farklı lokasyonda bulunan 4 adet maden cevherinin detaylı niteliksel ve niceliksel araştırmasının yapılabilmesi için sondaj çalışmaları planlanmaktadır. Krom, Altın, Platin ve Bakır madenleri için gerçekleştirilecek olan bu sondaj operasyonları gerçekleştirilmeden önce sondajın daha etkin, ekonomik ve hızlı olabilmesi için fizibilite aşaması saha ön incelemesi gerçekleştirilmiştir. Bu bağlamda, krom madeni için, Perroi Batres ve Kalimash loksayonları, platin madeni için Lumth lokasyonu, bakır madeni için Rubik ve Derven lokasyonları, altın madeni için ise Gjazuj lokasyonu detaylı olarak sondaja elverişlilik açısından incelenmiştir. 


\subsection{Krom maden sahaları (Perroi Batres ve Kalimash-3 lokasyonları)}

\subsubsection{Perroi Batres lokasyonu}

Planlama açısından Arnavutluk’a gönderilecek sondaj makinesinin çalışmaya başlayacağı ilk lokasyonun Perroi Batres lokasyonudur. Bölgenin deniz seviyesinden yüksekliği 1400 metredir. Bu lokasyonda toplam 2000-3000 m delgi gerçekleştirilmesi planlamaktadır. Arazi çalışmaları sırasında makinenin ulaşamayacağı yerler için $60^{\circ}-90^{\circ}$ arasında eğime sahip kuyuların açılması uygun görülmüştür. Makine bu bölgeye treyler üzerinde getirilmesi ve maden sahasına kadar yaklaşık $2 \mathrm{~km}$ palet üzerinde yürütülmesi planlanmıştır. Sondaj operasyonları için inşa edilmiş yollar boyunca oluşturulması öngörülen $10 \mathrm{~m}$ x $15 \mathrm{~m}$ boyutlara sahip sondaj platformu üzerinde operasyonların gerçekleştirilmesi planlanmıştır. (şekil 1).

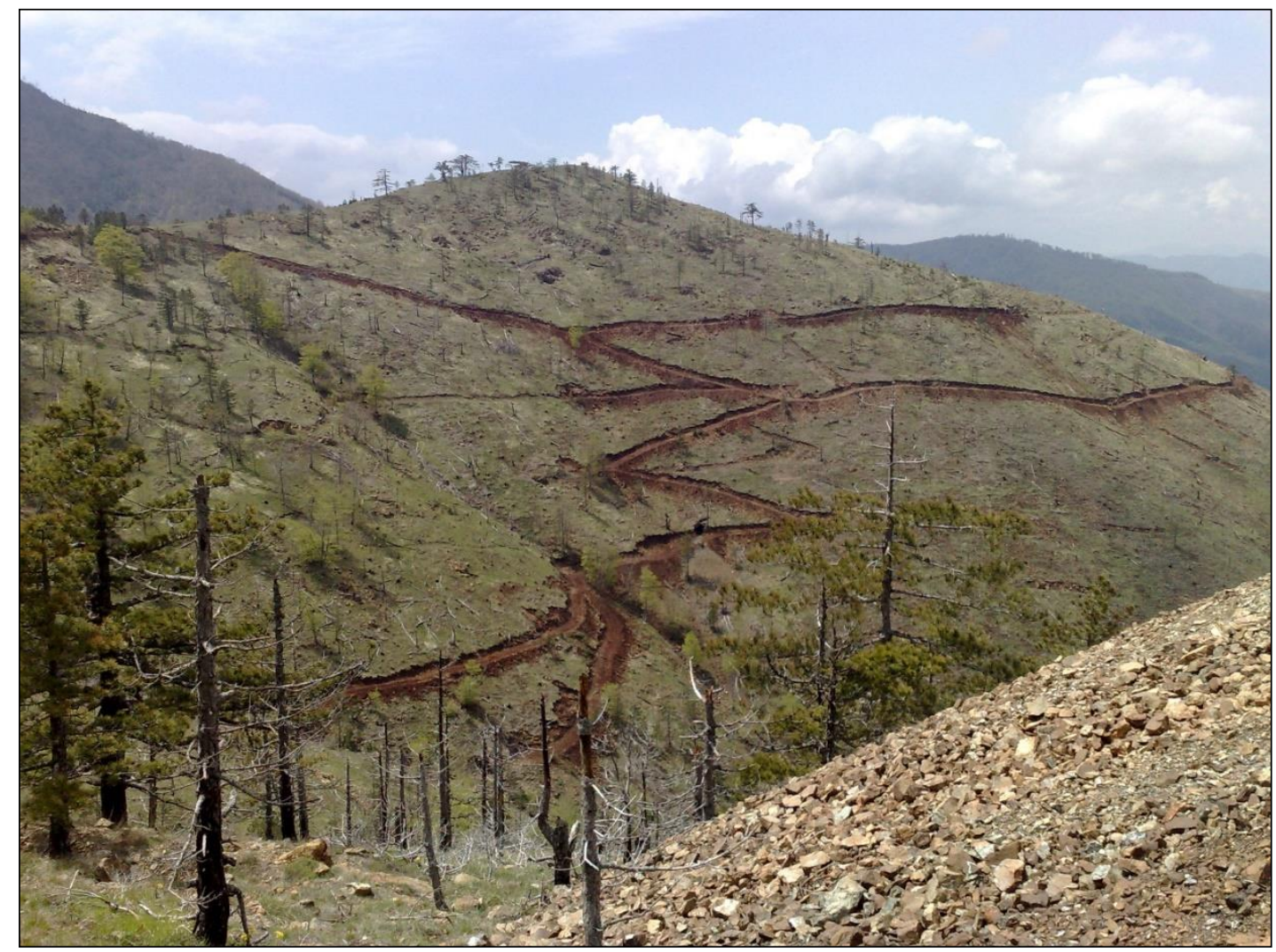

Şekil. 1. Perroi Batres lokasyonunda üzerinde sondajların yapılacağı yol

Gerçekleştirilen sha çalışmalarında sondaj yapılacak formasyonun ultra bazik kayaçlardan (Dünit, Peridotit, Serpantinit vs.) oluştuğu anlaşılmaktadır. Bölge çok ciddi bir tektonizma etkisine maruz kalmış ve kaya ortamında çok sayıda çatlak ve fay setlerinin oluşmasına yol açmıştır. Bu durum civardaki kayaçların yer yer bozunma zonları oluşmasına sebep olmuştur. Çalışılacak sahada gözlenen bozunma zonlarının çok fazla olması, sondaj sırasında takım sıkışması ve kuyu çökmesini berberinde getirebilir, bu nedenle sondaj katkısı olarak puzolonik malzeme ve bentonit karışımının doğru oranlarda yapılması büyük önem arz etmektedir. Ayrıca, bölgede 6 adet süreksizlik seti saptanmış olup, süreksizlik sıklığı ve devamlılığı oldukça yüksektir (şekil 2). 


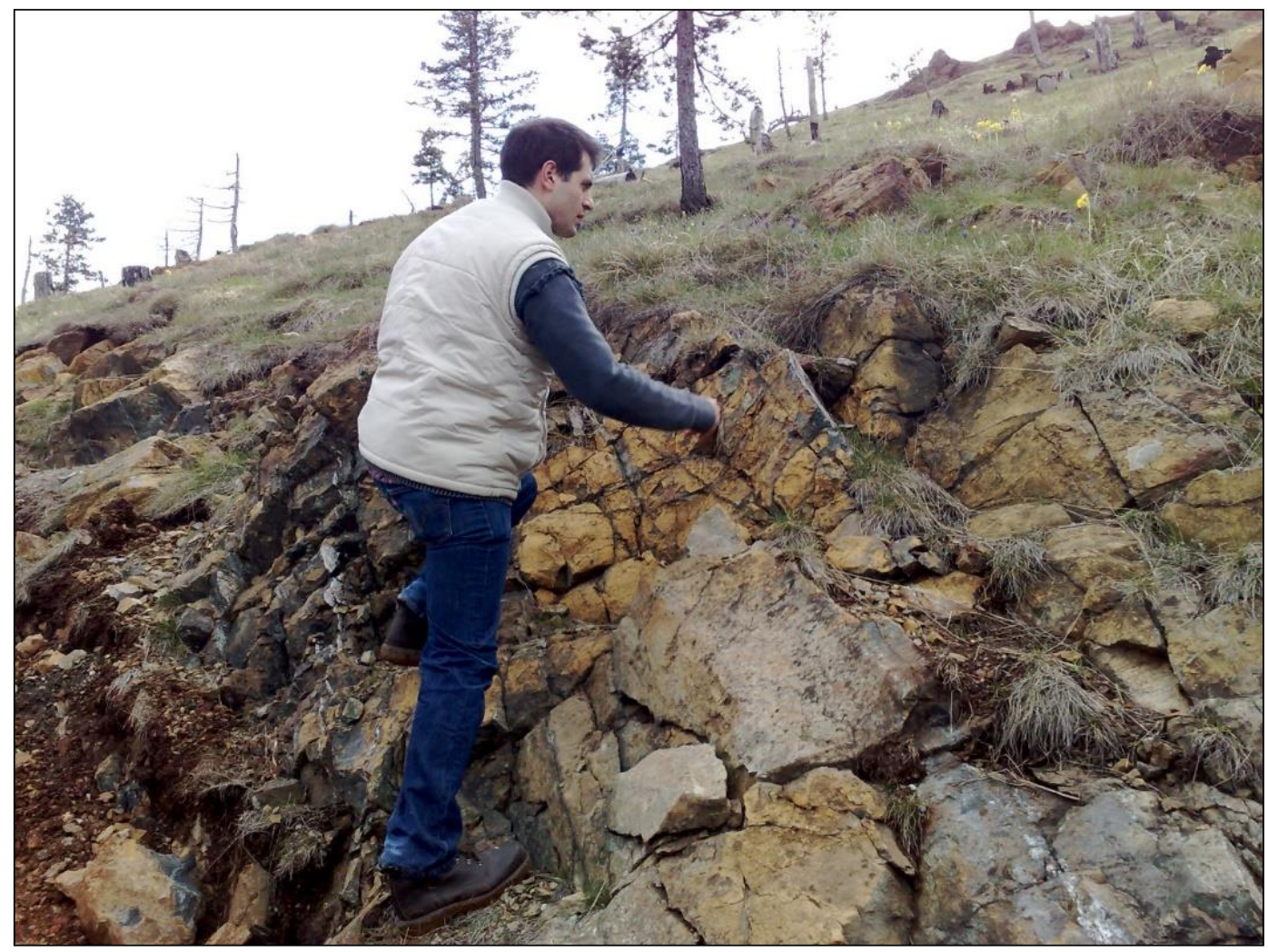

Şekil. 2. Perroi Batres çalışma sahasındaki bir mostra zonu ve süreksizlik setleri

Bölgedeki kırık çatlak oluşumları ve aldığı yıllık yă̆ış (yaklaşık 1200mm/yıl) göz önünde bulundurulursa yeraltı su seviyesi açısından bölge RC sondaja müsait değildir. Ayrıca karotlu sondaj için su temini traktör ya da tankerle yapılması uygun görülmüştür. Eğer yüzey suyundan sondaj sahasına su pompalanma alternatifi değerlendirilirse, en yakın yüzey suyunu pompalamak için $300 \mathrm{~m}$ yüksekliğe su basabilecek bir pompaya ve 700-800 metrelik 30 bar basınca dayanıklı bir hortum gerekecektir. Mazotun ise sondaj sahasına 100 litrelik varillerle parti parti getirilmesi en kolay seçenek olarak gözükmektedir.

Çalışma sahasına en yakın şehir 40 km uzaklıktaki Kukes şehridir. Personel konaklaması bu bölgedeki bir otelde gerçekleşecektir. Bölgede torna ve kaynak işlerinin yapılabileceği iş yerleri mevcuttur. Sondaj sahasında GSM operatörü sorunsuz şekilde çalışmaktadır.

Buradaki sondaj operasyonu bittikten sonra, makine tekrar $2 \mathrm{~km}$ palet üzerinde yürüttükten sonra, treyler ile Perroi Batres'e $11 \mathrm{~km}$ uzaklıktaki Kalimash-3 bölgesine götürülmesi planlanmıştır.

\subsubsection{Kalimash-3 lokasyonu:}

Makine Perroi Batresten ayrilıp $11 \mathrm{~km}$ treyler üzerinde seyahat ettikten sonra Kalimash-3 lokasyonuna gelecek ve burada palet üzerinde 7-8 km kadar ilerleyecektir. İlerleyeceği yol yer yer çok daralmaktadır. Bu nedenle yolun genişletilmesi gerekmektedir. Bu lokasyonda toplamda minimum $1000 \mathrm{~m}$ delgi planlanmakta olup, sondaj çalışmalarından elde edilecek verilere göre maden rezervini detaylandırabilmek için 2000-2500m delginin bu bölgede gerekli olabileceği öngörülmektedir.

Sondaj lokasyonu eski bir açık maden işletmesinin üzerinde planlanmıştır ve topoğrafya eğimli değildir (şekil 3). Daha önce işletilen maden ocağı krom fiyatlarının düşmesiyle rantabilitesini kaybetmiştir. Güncel krom fiyatlarıyla bölgedeki maden rezervinin ekonomik olup olmadığı araştırılacaktır. 


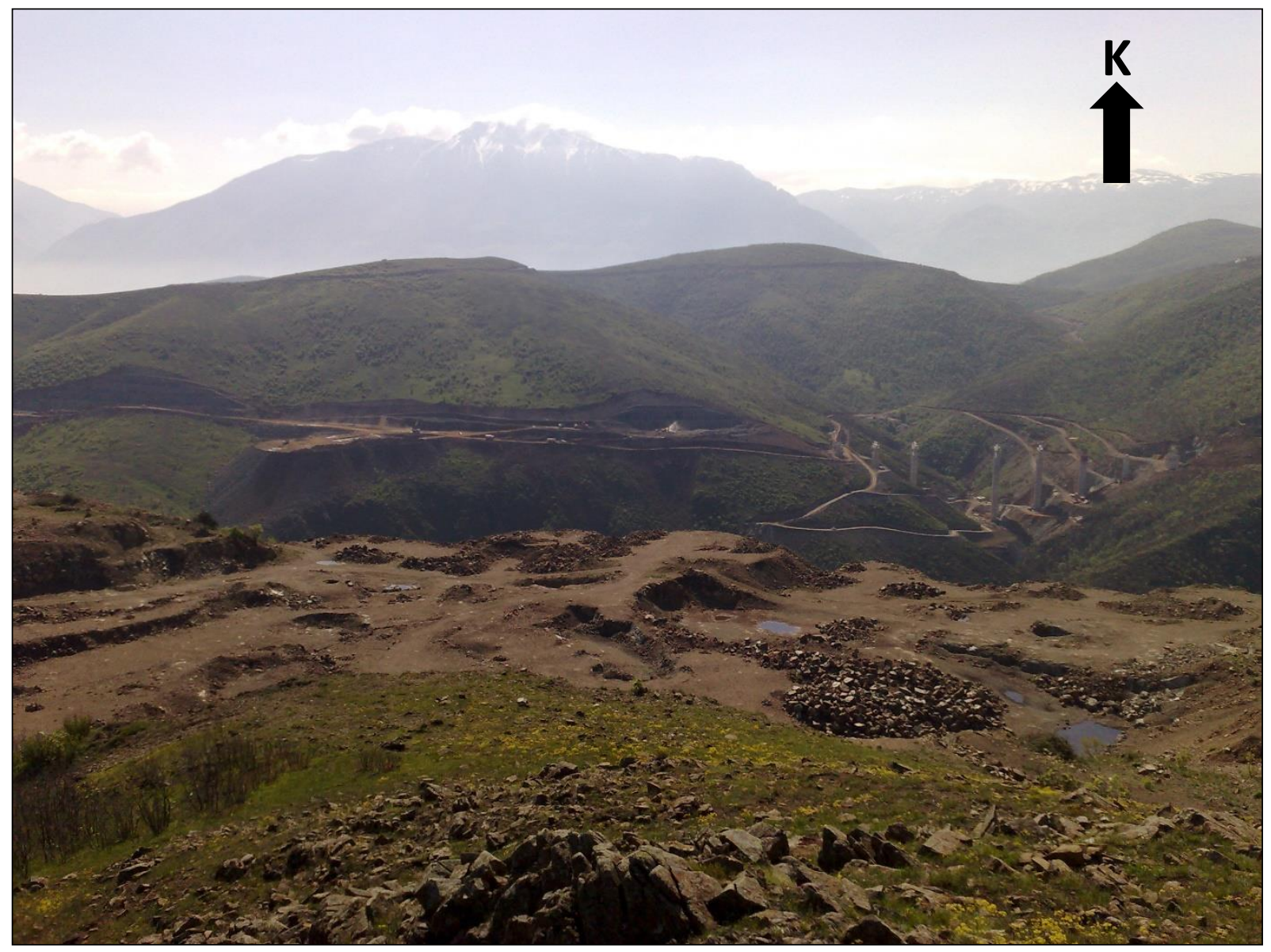

Şekil. 3. Kalimash-3 lokasyonundaki sondaj sahası (eski açık işletme)

Ayrıca bu açık işletmenin hemen Güneyine yol ve sondaj platformu (10m x 15m) açılıp bir miktar da orada sondaj yapılması planlanmıştır. Söz konusu sondajlar, güneyde açılacak proje içi ulaşım yolu üzerinde gerçekleştirilecek olup, 6-7 adet yaklaşık 50'şer metrelik kuyular şeklinde düşünülmektedir. Bu bölge yeraltı suyu ve cevherleşmeye bağlı hedef sondaj derinliği göz önünde bulundurulduğunda RC sondaj için uygun olarak değerlendirilebilir. Bölge sondaj suyu açısından fakir denecek kadar kısıtlı bir konumdadır. Bu lokasyonun sondaj suyu temini için tek yolu tanker ya da traktörle su taşınmasıdır. Aynı şekilde mazot da sondaj sahasına 100 litrelik varillerle rahatça taşınabilir.

Sondaj yapılacak formasyon ultrabazik kayaçlardan (Dünit, peridotit, serpantinit vs.) oluşmaktadır. Bu bölge de Peroi Batres bölgesi gibi tektonik etkilere maruz kaldığından kaya ortamında birçok kırık çatlak sistemleri ve faylanmalar mevcuttur. Bölge içerisinde incelenen mostrada 5-6 adet süreksizlik seti bulunmakta ve Peroi Batres lokasyonundaki gibi bu süreksizliklerin devamlılıkları ve sıklıkları oldukça fazladır. Ancak bozunma zonları bir önceki lokasyondaki kadar yaygın değildir. Bu bölge için de sondaj katkısı olarak puzolonik malzeme ve bentonit karışımının doğru oranlarda kullanılması sondaj performansını arttıracaktır.

Bölgenin deniz seviyesinden yüksekliği 800 m civarındadır. GSM operatörü bölgede sorunsuz şekilde çalışmaktadır. Çalışma sahasına en yakın şehir gene kukes şehridir. Kukes, çalışma sahası olan Kalimash-3 lokasyonuna 40 km uzaklıktadır ve bu mesafe, yetersiz yol koşulları nedeniyle 1-1,5 saat sürebilmektedir.

\subsection{Platin Maden Sahası (Lumth Lokasyonu)}

Platin madeni sahası Lumth lokasyonunda bulunmaktadır. Bu sahaya en yakın şehir Rreshen şehridir. Sondaj sahasının deniz seviyesinden yüksekliği 250 metredir. Sondaj makinesinin Kalimash-3 (Krom maden sahası) lokasyonundaki işi bitince, 7-8 km palet üzerinde yürüyecek ve treylerle $120 \mathrm{~km}$ uzaklıktaki (4 saat) Lumth Lokasyonuna ulaşacak ve 1-2 km de buradan Platin sondaj sahasına gidebilmek için palet üzerinde yürüyecektir. Bölgede sondaj sahasına giden eski bir yol mevcuttur ancak ama yolun bazı yerlerde revizyona ihtiyacı bulunmaktadır (şekil 4). Yapılacak sondajlar, revize edilecek bu yollar üzerindeki sondaj platformlarında (10m x 15m) yapılacaktır. Maden rezervinin geometrisini ve niteliğini belirlemek amacıyla bu sahada her biri aşağı yukarı 200'er metrelik 2-3 kuyu açılması planlamaktadır. Kuyu eğimlerinin $80^{\circ}-90^{\circ}$ arasında değişmesi öngörülmektedir. 


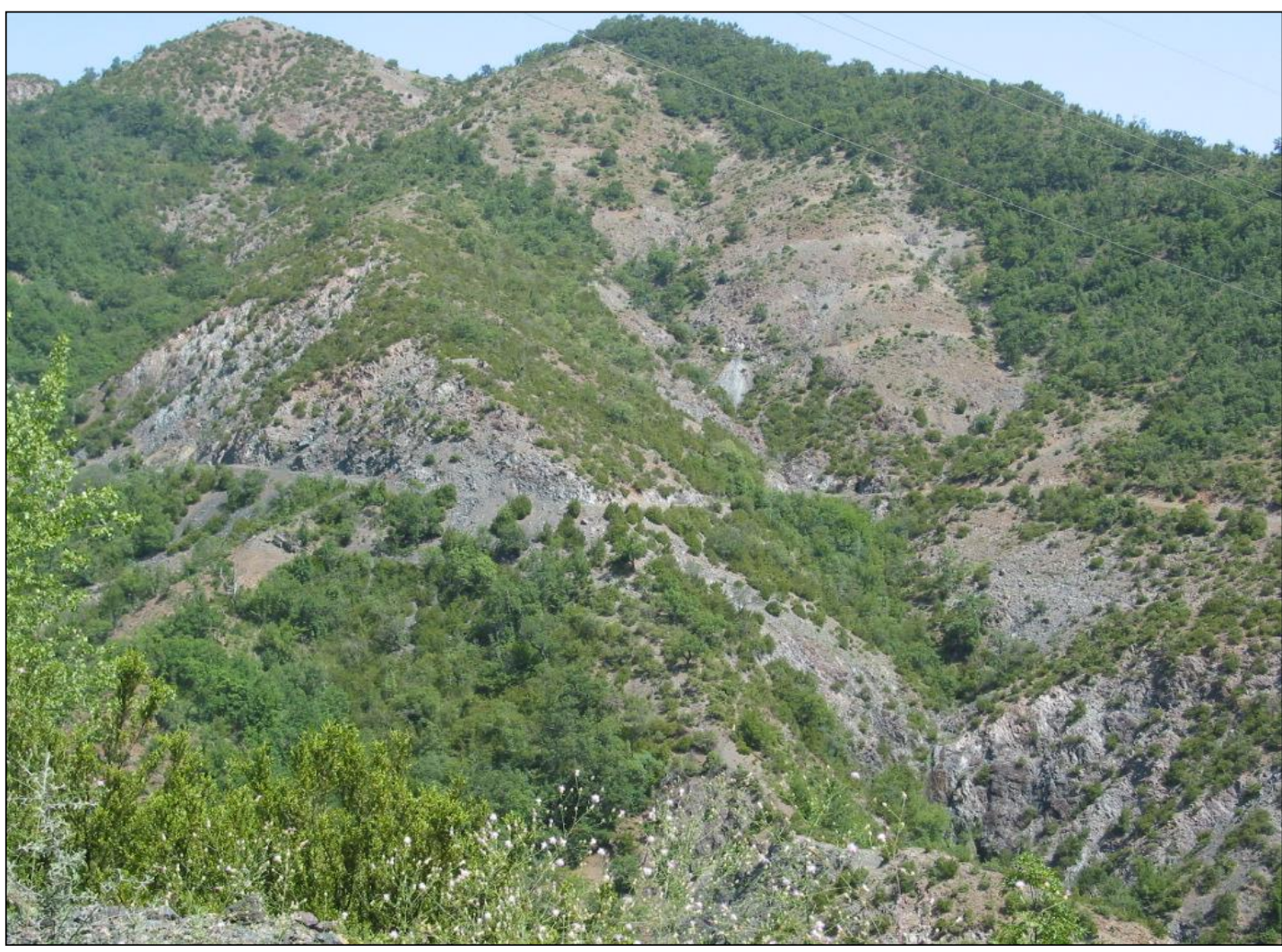

Şekil. 4. Lumth lokasyonu platin madeni araştırma sahası

Platin ve bakır gibi madenler bazik kayaçların içinde cevherleşir, dolayısıyla sondaj operasyonlarının gerçekleştirileceği jeolojik formasyonda bazik kayaçlar hâkim. Bölgenin çok ciddi tektonik aktivitelere maruz kalmış olduğu arazide gözlenen faylardan ve kırıkılı çatlaklı kayaç yapısından anlaşılmaktadır. Lumth lokasyonu ultrabazik-bazik kontak zonunu da içine aldığından bol miktarda bozunma gözlenmiştir. Bozunma zonlarında, düşük plastisiteli kile (CL) sıklıkla rastlanmıştır. Bu nedenle özellikle bu sahada gerçekleşecek sondajlarda sondaj katkısı olarak kullanılacak polimer seçimi çok dikkatli yapılmalıdır.

Hedef derinlik açısından bu bölge de RC sondaja müsait değildir fakat bu bölge için herhangi bir artezyen durumu söz konusu olmaz. Ayrıca, Sondaj suyu temini için yakınlarda herhangi bir kaynak saptanamamış, önceki sondaj lokasyonlarındaki gibi mazot ve suyun sahaya traktör ya da tankerle birkaç seferde taşınması uygun görülmüştür. Personel konaklaması için çalışma sahasına en yakın şehir olan Rreshen incelenmiştir. Bu şehirde sondaj operasyonu sırasında ihtiyaç duyulabilecek torna, kaynak vs. gibi temel işlerin yaptırılabileceği bir sanayi bölgesi bulunmaktadır. Sahada GSM operatörü sorunsuz çalışmaktadır.

Buradaki sondaj işleri bittikten sonra, sondaj makinesinin $5 \mathrm{~km}$ palet üzerinde Rubik lokasyonunda bulunan Bakır sahasına yürütülmesi planlanmıştır. (Lumth-Rubik arası 5-6 km).

\subsection{Bakır Maden Sahaları (Rubik ve Derven Lokasyonları)}

Sondaj makinesinin Lumth lokasyonundaki sondaj işleri bittikten sonra hiç treylere binmeden direk palet üzerinde $5 \mathrm{~km}$ kadar yürüdükten sonra Rubik lokasyonundaki bakır sahasına gelmesi en ekonomik seçenek olarak görülmektedir. Bakır sahasında da yolların yer yer revizyona ihtiyacı vardır. Bu sahanın deniz seviyesinden yüksekliği 520 metredir. Yer altı suyu koşulları ve jeolojik formasyon özellikleri Lumth lokasyonundaki platin sahasıyla bezer özellikler göstermekte olup herhangi bir basınçlı akifere rastlanmamıştır.

Mineralize olmuş zonun tahmini derinliği göz önüne alınarak bu bölgede 2-3 adet 200'er metrelik kuyular planlanmaktadır. Ancak cevherleşmenin düşey devamll1 lğına bağlı olarak kuyularda 300 metreye kadar sondaja devam etme durumu da değerlendirilmiştir. Bu koşullar altında hedef derinlik çok fazla olduğundan RC sondaj bu lokasyon için uygun görünmemektedir. Mineralize zonun kesilebilmesi için bazı kuyularda $60^{\circ}-70^{\circ}$ arasında değişen kuyu eğimleri planlanmıştır. Sondaj suyu için burada da herhangi bir kaynak bulunmamaktadır, en mantıklı çözüm bu saha için de traktör ya da tankerle taşımadır. Konaklama çalışma sahasına en yakın şehir olan Rreshen de gerçekleşecektir. Bu şehirde iş sırasında ihtiyaç duyulabilecek torna, kaynak vs. gibi temel işlerin yaptırılabileceği bir sanayi bölgesi bulunmaktadır. Ayrıca mazot da bu şehirden sağlanacaktır. Şehrin sondaj sahasına uzaklığı 30 dk mesafededir. Ayrıca, sahada GSM operastörü sorunsuz çalışmaktadır.

Makine buradaki sondaj işlerini bitirdikten sonra tekrar palet üzerinde $5 \mathrm{~km}$ kadar orman yolundan yürüdükten sonra treylere binecek ve altın işi için $31 \mathrm{~km}$ uzaklıktaki (45-55 dk) Gjazuj lokasyonuna ulaşacaktır. 


\subsection{Altın Maden Sahası (Gjazuj Lokasyonu)}

Gjazuj lokasyonuna ulaşan sondaj makinesinin açılacak ulaşım yolları üzerinde $1 \mathrm{~km}$ palet üzerinde yürüdükten sonra oluşturulan sondaj platformlarında operasyona başlaması planlanmıştır. Bu lokasyonda toplamda 500-600 metre sondaj yapılması öngörülmektedir. Söz konusu maden sahasında eski bir altın işletmesi bulunmaktadır ve maden sahası civarında 3 adet maden galerisi gözlenmiştir. Maden sahasında daha önce yeterli sayıda sondaj yapılmış, kesitler çizilmiştir. Ancak, önceki maden işletmesi eski teknoloji ile çalıştığından çıkarılan maden rantabl olmadığı için işletme kapanmıştır. Burada yeni madencilik teknikleriyle işletilmesi planlanan bu altın madeninde güvenli tarafta kalmak adına 2-3 adet maximum derinliği 150-170 metre olan kuyu açılması planlamaktadır. Kuyu eğimlerinin $70^{\circ}-90^{\circ}$ arasında değişebileceği belirlenmiştir.

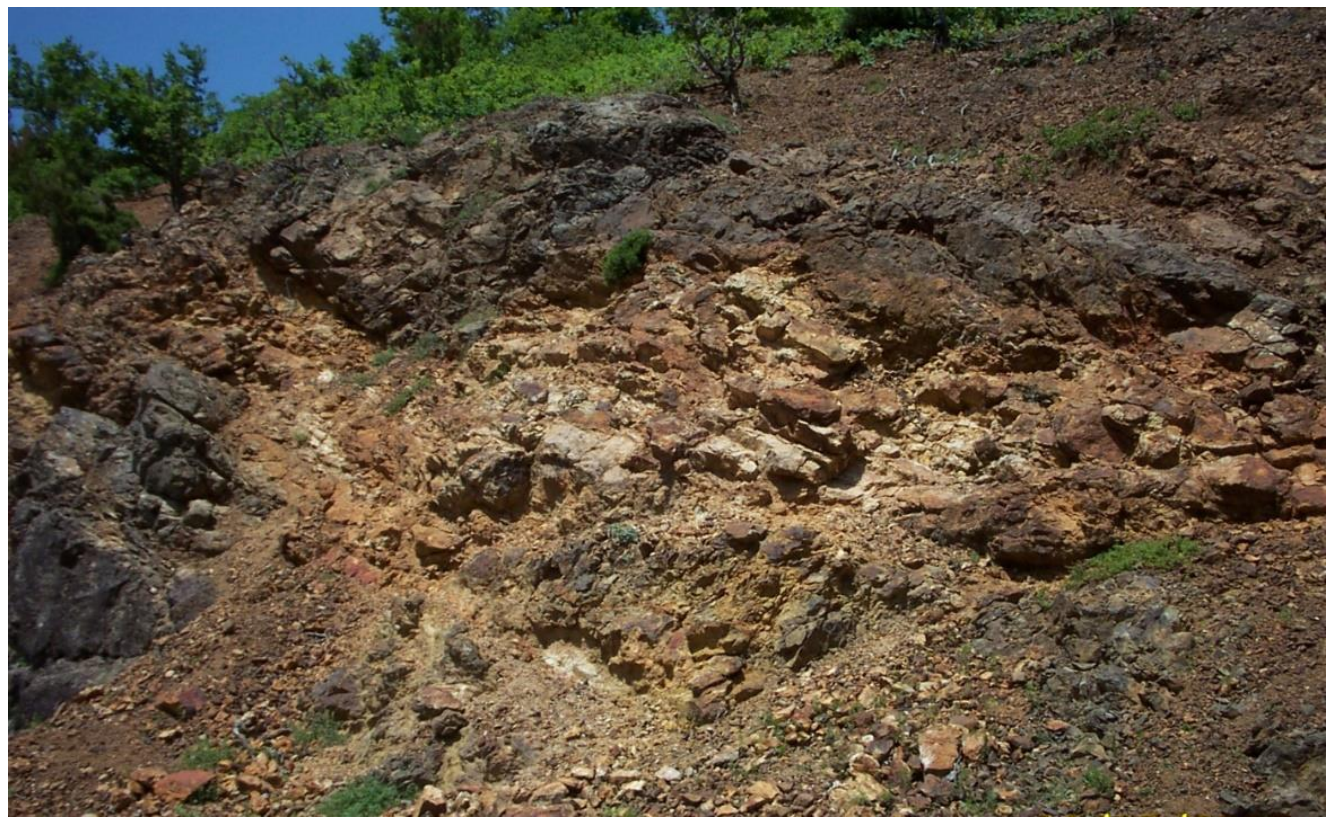

Şekil. 5. Gjazuj lokasyonu (altın madeni) jeolojik formasyon ve ufalanmış kaya mostrası

Bu formasyonda da bazik kayaçlar hakimdir ve herhangi bir ultrabazik-bazik kontağı gözlenmemektedir. Tektonizma etkisi çok fazla olmamasına rağmen kayaçlar sık süreksizlik setlerine sahiptir ve ufalandıkları gözlenmiştir (şekil 5). Bölge de yer yer bozunma zonları saptanmıştır ama bozunma etkisi diğer şantiyelerdeki gibi çok fazla değildir. Ayrıca bu lokasyon için sondaj suyunun 20-30 metre aşağıdan uygun debiyle akan dereden bir pompa aracıllğıyla sağlanması uygun görülmüştür. Bölgeye mazot gene traktörle yada 100 litrelik varillerle parti parti sağlanacaktır. Bu bölge için de personel konaklaması açısından en uygun yerleşim birimi çalışma sahasına 45 dakika mesafedeki Rreshen şehridir. Ayrıca, burada da GSM operatörü her yerde olduğu gibi sorunsuz biçimde çalışmaktadır.

\section{Sonuçlar ve tartışma}

Sondaj operasyonları özellikle derin ve karot numune alınan operasyonlar için son derece pahalıdır ve uzmanlık gerektirmektedir. Operasyonlara başlanmadan önce gerçekleştirilecek fizibilite aşaması etütler kapsamında gerçekleştirilen saha incelemeleri, sondaj sırasında karşılaşılacak muhtemel sorunların öngörülmesi ve engellenmesi açısından büyük önem taşımaktadır. Ayrıca, gerçekleştirilen bu çalışma sübjektif mühendislik yaklaşımları içermekte olup, sahadan elde edilen verilerin ve varılan sonuçların tecrübeye bağlı olarak mühendisten mühendise değişebileceği hesaba katılmalıdır. Bununla beraber, madencilik ve sondaj alanında teknoloji her geçen gün gelişmektedir. Gelişen teknolojinin farklı mühendislik çözümlerini de beraberinde getireceği göz önüne alındığında sahanın sondaja uygunluğu ve rantabilitesi de günden güne değişecektir.

Arnavutluk ülkesinde farklı lokasyonlarda, krom platin altın ve bakır madenlerinin rezerv miktarlarının belirlenebilmesi için sondaj programı planlanmıştır. Bu bağlamda, Perroi Batres, Kalimash-3, Lumth, Rubik - Devren ve Gjazuj lokasyonlarında gerçekleştirilecek olan sondaj operasyonları için fizibilite aşaması etütler gerçekleştirilmiştir. Gerçekleştirilen çalışmalardan aşağıdaki sonuçlara ulaşıılmıştır:

- Kuyu başına gerçekleştirilecek delgi miktarı ve jeolojik formasyonların ve hidrojeolojik koşulların genel olarak sondaj operasyonları açısından uygunluğu göz önüne alındığında ters sirkülasyonlu sondaj tekniğinin söz konusu sahalarda uygulanmasının daha uygun olduğu sonucuna varılmıştır.

- Sondaj makinesinin sırasıyla, Perroi Batres, Kalimash-3, Lumth, Rubik - Devren ve Gjazuj lokasyonlarında iş yapmasının ulaşım ve lokal işçi temini açısından daha ekonomik olduğu sonucuna varılmışıtır.

- Sondaj sahasına yakıt ve su temini için gerekli ön çalışmalar gerçekleştirilmiş ve her bir sondaj sahasının kendine özel koşulları dikkate alınarak yakıt ve su temini için gerekli işlemler belirlenmiştir. 
- Jeolojik formasyonların sondaj operasyonlarına muhtemel etkileri de ayrıca her bir sondaj lokasyonu için göz önüne alınmış olup, ileri derecede eklemlenmiş ve çok kırklı çatlaklı zonlar için gerekli sondaj katkılarının kullanılması gerekliliği göz önüne alınmıştır.

\section{Teşekkürler}

Yazar bu çalışmada araştırma maliyetlerini yüklenen Spektra Jeotek San. ve Tic. AŞ ailesine, özellikle çalışmaya katkıda bulunan Jeoloji Mühendisi Sn. A. Levent Okay ve ekibine teşekkür eder.

\section{Referanslar}

Canoglu, M. C. (2018). Investigation of the Suitability of a Pipe Stock Site in Terms of Geotechnical Characterization and Engineering Design Parameters Considering the Economic Aspects. Hittite Journal of Science and Engineering, 5(2), 147-154.

Canoglu, M.C. \& Gökkurt Baki, O. (2018). Feasibility stage design assessment for transforming an unproductive dam into a sanitary landfill site. Fresenius Environmental Bulletin, 27(12A), 9179-9188.

Canoglu, M.C. \& Kurtuluş, B. (2017a). Determination of the dam axis permeability for the design and the optimization of grout curtain: An example from Orhanlar Dam (Kütahya-Pazarlar). Periodicals of Engineering and Natural Sciences, 5(1), 37-43.

Canoglu, M.C. ve Kurtuluş, B. (2017b). Permeability of Savcıbey Dam (Bilecik) axis location and design of grout curtain. Bulletin of Mineral Research and Exploration, 154, 157-168.

Cao, P., Liu, M., Chen, Z., Chen, B. \& Zhao, Q. (2018). Theory calculation and testing of air injection parameters in ice core drilling with air reverse circulation. Polar Science, 17, 23-32.

Kurtuluş, C. \& Bozkurt, A. (2010). Geophysical and Drill-hole Investigations for Detecting Groundwater Aquifers Around Başiskele-Kocaeli. Applied Geoscience, 2, 1-9.

Navarro, J., Segarra, P., SanchidriánJ.A., Castedo, R. \& López, L.M. (2019). Assessment of drilling deviations in underground operations. Tunneling and Underground Space Tecnology, 83, 254-261.

Özbayoğlu, Y. (1979). Elmaslı Sondajlarda Kuyu Sapmaları. Bilimsel Madencilik Dergisi, 18 (2), 33-40.

Sneddon, A., Mearns, K. \& Flin, R. (2013). Stress, fatigue, situation awareness and safety in offshore drilling crews. Safety Science, $56,80-88$. 